\title{
CREDIT RATIONING BY DEPOSIT MONEY BANKS AND IMPLICATION ON AGRICULTURAL OUTPUT IN NIGERIA
}

\author{
EGWU, P. N; NNABU, BERNARD E.; MBAM, B. N.; AND NWIBO, S. U.
}

(Received 20 April 2020; Revision Accepted 11 October 2020)

\begin{abstract}
The study examined the effects of credit rationing by deposit money banks on the performance of agriculture in Nigeria using secondary data between 1981 and 2016 obtained from the CBN Statistical bulletin. The study applied both Augmented Dickey-Fuller (ADF) and Phillips-Perron (PP) unit root test to determine the order of integration of each variable, Johansen cointegration and Vector Error Correction Model (VECM) were employed to determine if there is a long run, the short-run relationship between credit rationing and agricultural output. The result showed that all the variables were integrated of order one. The results revealed that credit rationed for fishery has a short-run significant impact on agricultural output while credit rationed for cash crops, food crops, and livestock do not have a significant short-run impact on agricultural output. The findings further revealed that credit rationed for cash crops and livestock farming significantly decline agricultural output to the tune of $26.48 \%$ and $75.87 \%$ in the long run while credit rationed for food crops and fishery significantly result in $43.52 \%$ and $41.89 \%$ rise in agricultural output in the long run. Therefore, the study recommends the establishment of special financial institutional to give unconditional loans to farmers, raise credit rationing for food crop production above the current ceiling, and emphasis should be on exchange rate liberalization policy that will shift consumption from imported agricultural produce to local agricultural produce. These measures will promote farmers' access to funding which will invariably translate to a rise in agricultural output.
\end{abstract}

\section{KEYWORDS: Credit, Rationing, Money Deposit Bank, Agriculture, Output, Nigeria}

\section{INTRODUCTION}

The need for agricultural credits to the various subsectors of agriculture is very important to increase diversification in agriculture. The credit market is faced by much imperfection, involving lack of collateral, lack of information management, high level of illiteracy of the borrowers and loan default among borrowers. This statement was affirmed by the words of

Olomola, (1999), where he noted that information asymmetry most times leads to challenges in adverse selection and moral problems, which cause the reluctance of the commercial banks to lend to smallscale farmers. Adverse selection is made when banks do not know the particular capabilities of the borrowers, especially in terms of the credibility of their projects.

Over the years, agricultural production is seen not to have achieved its objectives in contributing to our economy despite the advancement in technologies and policy incentives by the government. This is attributed to the inability of the financial sector to deliver the services which have led to low investment in agriculture. This low investment in agriculture has been associated with low finance which reduces the access to modern technology for increased agricultural production (Salami, Kamara and Brixiova, 2010). There have been efforts to increase the agricultural investment but the sector is yet to be well-capitalized. Farmers and other stakeholders in the real sector of the economy need credit to enable them to meet up with the challenges of low agricultural financing, low-level adoption of new technologies, and low productivity.

The important role of credit in agricultural enterprise development and sustainability has prompted the Federal Government of Nigeria to establish credit schemes such as the Agricultural Credit Support Scheme (ACSS) to ensure farmers access to agricultural credit (Idris, 2010). These schemes were designed to encourage lending to the agricultural sector by providing guarantees against the inherent risk in

Egwu, P. N., Department of Agricultural Economics and Extension Services, Ebonyi State University, Abakaliki, Nigeria.

Nnabu, Bernard E., Department of Economics, Ebonyi State University, Abakaliki, Nigeria.

Mbam, B. N., Department of Agricultural Economics and Extension Services, Ebonyi State University, Abakaliki, Nigeria.

Nwibo, S. U., Department of Agricultural Economics and Extension Services, Ebonyi State University, Abakaliki, Nigeria. 
agricultural lending. Despite these provisions, with attractive incentives and concessions with the implementation of the various agricultural policies, agricultural production is still dwindling. Bigsten, Collier, Dercon, Fefchamps, Gauthier, Gunning \& Soderborn (2003) argued that policies leading to repression of financial markets reduce the incentives to investment. This sometimes suggests why banks try to ration credit which he said will pose some problems to production processes as it has serious implications for growth and equity objectives of development policy.

When credit is rationed, some borrowers cannot obtain the amount of credit they desire at the prevailing interest rate, nor can they secure more credit by offering to pay a higher interest rate. In such circumstances, liquidity can become a binding constraint on farmers' operations. Yet the rationing behaviour by the banks may be due to their rational and efficient response to information and problems inherent in agricultural credit markets. Cecilia, Omonona and Victor (2012) argued that the reasons behind bank's credit rationing include borrower's observable characteristic like age, economic scale of the firm, gender, wealth, experience and credit history, firm characteristics (risk profile, earning and business experience), loan characteristics like amount demanded, collateral offered and interest rate. Bank's credit rationing can also be a result of the creditworthiness of the borrower, viability of the proposed agricultural project which will also give an insight into the repayment capacity of the borrower (Cecilia, Omonona and Victor, 2012).

It is widely believed that farm households are credit constrained and the provision of credit would lead to an increase in production and income. The banking system helps to mobilize the collection and storage of savings to boost economic growth and development (Nzotta, 2004). Contrary to this, lending institutions apply some criteria such as rationing techniques by limiting access to credit by the poor just to clear the credit market due to the problems associated with adverse selection and moral hazard thus increasing rural poverty. In the case of moral hazards, some borrowers default in loan repayment, forcing the banks into credit rationing which the banks use to shade off such client.

Deposit money banks perceive agricultural credit as risky and seek to channel credit to less risky sectors. The reason was seen in the statement of Arene (1992) that loan default is random and is influenced by the erratic behaviour of borrowers. When the repayment declines, lenders tend to deny some people from obtaining a loan from them hence credit rationing. It is, therefore, pertinent to investigate how formal lenders respond to the borrowing demands of farm households in Nigeria. Again, deposit money banks are very sensitive when it comes to credit facilities, the repayment time and payment of interest on due time matter a lot to them. In view of the above situation, this study aims to find out how the credit rationing by the deposit money banks have been contributing to the performance of the agricultural sector in Nigeria. This is because agriculture unarguably remains the mainstay of Nigeria's economy in terms of employment and food production.

\section{LITERATURE REVIEW}

Credit rationing is a situation in which borrowers are given just some or none of the amount they request from lenders even though they are willing to pay the market rates of the cost of borrowing (interest rates). This occurs as a result of the existence of information asymmetry. Therefore, it is a situation in which the equilibrium price (interest rate) does not ensure the efficient allocation of credit; hence, rationing is performed instead of allocation using a non-price mechanism. The studies by Jaffee and Russell (1976) and Stiglitz and Weiss (1981) demonstrated that the difficulty in gaining access to credit might persist even in equilibrium markets using information-based models. To them, interest rates cannot function as an allocator of credit in so far as information asymmetries exist and therefore credit rationing may persist even in the face of interest rate liberalization.

Stiglitz and Weiss (1981) model were based on imperfect credit markets characterized by information asymmetry, which makes it too costly for banks to obtain accurate information on the borrowers and monitor them. They established that when agency problems such as information asymmetry and moral hazards impact the availability of credit and the capital, the phenomenon is known as credit rationing. The model assumes the existence of too many banks that seek to maximize profits through their choice of interest and collateral and many potential borrowers seek to maximize their profits through the choice of projects. The idea here is that the probability of success of the projects is unknown to the bank but known to the firms due to information asymmetry. In other words, credit rationing is said to occur, if, among loan applicants who appear to be the same, some get credit while others do not, or a certain group of persons are unable to obtain credit or can only obtain credit at a much higher price. Bank's credit rationing may be influenced by borrowers' observable features, firms' characteristics, and loan characteristics.

The value of the collateral offered by a firm also influences the credit rationing behaviour of the bank. According to Chan and Kanatas (1985), collateral reduces the information asymmetry between the small and medium enterprises and the financial institution. The magnitude of a firm's internal financing sources also affects the banks' credit rationing behaviour. This has been confirmed by Beck (2007) who argues that the availability of finance to new small and medium enterprises can be influenced by both borrower-specific and systemic factors. Barbosa and Moraes (2004) also pointed out that the borrower's pacific factor includes variables largely controllable by a firm such as managerial competencies, quality of business information, availability of collateral and networking, etc. Coco (2000) points out that collateral helps to reduce informational asymmetries and moral hazard problems that arise between banks and entrepreneurs.

Access to credit and credit rationing are two different issues according to the microfinance institutions type since the microfinance institutions may be differentiated by their lending policies, mission drift, organizational form, and institutional transformation as well as by their 
disclosure and transparency (Akoten, Sawada and Otsuka, 2006; Von Pischke, 2008). It is clear that access to credit by micro and small agricultural enterprises is difficult but the extent and severity of this problem is yet to be discovered. This situation, therefore, calls for an empirical estimation to determine the extent to which loan, firm and borrower characteristics determine the access to credit and rationing of credit in microfinance and the extent to which institutional factors influence the rationing and credit access. Various researchers have concluded that credit rationing exists in most developing countries. According to Duong and Izumida (2002), the terms and conditions under which credit is transacted vary substantially based on the characteristics of the borrower and the lender and the relationship between them. In other words, borrower-lender variables determine the terms of a credit contract.

Empirically, Doan, Gibson, and Holmes (2010) employed a probit model with a binary variable representing whether a household was credit constrained or not. The study focuses on those that were quantity rationed and price rationed. The explanatory variables in the model include household size, income, age, gender, education, assets, and the proportion of borrowing households within a radius of 1 kilometer, and distance to the nearest bank within the award. The results show that higher-income reduces the likelihood of being credit constrained, even though all the studied households were poor. Income also has a Ushaped effect on the probability of credit constraints-a result that is contrary to Chen and Chivakul (2008), who found an inverted U-shape effect for general households rather than for the poor in Bosnia and Herzegovina.

Some other studies have tried to explore the connection between credit availability and agricultural output. These studies include among others Sugato Chakravarty (2002), Jimenez and Saurina (2003), Subbotin (2005), Atzeni and Piga (2007), Blumberg and Latterie (2008), Steijvers (2008), Becheti et al (2009), Carbo-Valverde et al. (2011), Armstrong, Davis, Liadze, \& Rienzo (2013), Tian (2012) and Asante-Addo, Mockshell, Siddig, and Zeller (2016) . What is clear however from all these studies is that they all tend to pursue similar objectives which range from investigating the determinants of agriculture credit rationing; examining the structure, pattern, and trends of credit rationing to assessing the influence of credit rationing by deposit money banks on agriculture output productivity level.

In Nigeria, there have been quite a large number of empirical studies conducted on agriculture credit rationing by deposit money banks in Nigeria and other countries. For instance, Sanusi and Adedeji (2010) studied small-scale farmers' access to formal sources of credit in the Ogbomosho zone of Oyo state used a probity model based on a purposive sample of 150 farmers. The studies revealed that level of education, membership in a cooperative, and contact with an extension agent and presence of collateral security positively and significantly affect the likelihood of farmers' access to formal credit, while farming experience negatively affects the probability of farmers having access to formal credit. In another study, Eneji, Umejiakwu, Silvanus, and Gwacham-Anisiobi (2013),
Olomola and Gyimah-Brempong (2014), Kofarmata, Applanaidu and Hassan (2014), Ayeomoni and Aladejana (2016) and Omorokunwa and Obadiaru (2016) went beyond the issue of access and attempt to consider credit rationing. The study focused on the analysis of rural households' access to the credit market as well as factors favoring credit constraints in Nigeria's Cross River State. Households that had borrowed from semiformal (MFIs) and informal sources are included in the study. However, the only aspect of rationing considered in the analysis involves borrowers being able to receive only a part of the loan applied for or nothing. However, it is imperative to note that there are some noticeable shortcomings observed from the works reviewed so far upon which basis this work is necessitated. For instance, Sugato Chakravarty (2002) fails to conduct the causality test. This inefficiency contributed to the result found which stipulates that there was no evidence of conceptualized foreign capital to include Agricultural credit, Interest Rate, and export earnings. Using Chenery and Stout's two-gap model, he concluded that credit rationing by deposit money banks has no significance on agriculture output productivity level in Nigeria. Studies by Subbotin (2005), Atzeni and Piga (2007) and Blumberg and Latterie (2008), made use of Ordinary Least Square (OLS) technique, failing to conduct both unit root and error correction model (ECM) test. The implication is that such studies may have suffered endogeneity problems. Again, Steijvers (2008) used both single and simultaneous equation system to determine the relationship between credit rationing and agriculture output productivity level and equally to test for endogeneity. The study found that there is a bidirectional relationship between credit rationing and agriculture output but failed to give clear and detailed reasons responsible for the presence of endogeneity. Of the studies conducted thus far, it could be said clearly that over $70 \%$ were able to establish a positive link between credit rationing and agriculture output, while less than $30 \%$ establish a negative relationship between the two. It is therefore apparent from the literature search and to the best of the knowledge that none of the studies has been able to examine the sectoral influence of credit rationing on agriculture output using agricultural credit scheme as a proxy for credit rationing in Nigeria. Hence, the study intends to identify the missing link which had over time resulted in the divergent conclusions from researchers and is set to correct most of the observed weaknesses by ensuring that all necessary econometrics tests are carried out.

\section{METHODOLOGY}

\section{Model Specification}

The model specification of this study followed Stiglitz and Weiss (1981) theoretical model which posited that credit rationing occurs basically because the lenders' expected return is not monotonically increasing in the interest rate. They believed that moral hazard causes the lenders' expected return to decline as the interest rate rises. Stiglitz and Weiss (1981) model were anchored on an earlier study by Jaffee (1971) that measured credit rationing as a commercial bank loan 
rate. In a later study, Emil (2007) modified the model and assumed credit rationing as an actual loan as a ratio of the granted loan amount to the requested loan amount. Therefore, following postulations of these previous studies, the model is specified as

$\begin{array}{llll}A G O & = & f & (B C R)\end{array}$ 1

where AGO is agricultural output and BCR is the loan granted by deposit money bank to agriculture. Agricultural loan (agricultural credit rationing) is disaggregated into credit rationed for cash crops (CPS), food crops (FCP), livestock (LSK) and fish farming (FHR). The model is thus re-specified as:

$A G O=f$ (CPS, FCP, LSK, FHR)

However, exchange rate variation is incorporated in equation 2 since it not only determines the real value of credit rationed by deposit money banks but also influences the competitiveness of Nigeria's cash crops in the global market and as well shift consumption from imported agricultural produce to domestic produce. The equation is re-specified in its functional form as follows:

$A G O=f$ (CPS, FCP, LSK, FHR, EXR) The equation is specified in log-linear form as $\log A G O t=\alpha 0+\alpha 1 \log C P S t+\alpha 2 \log F C P t+\alpha 3 \log L S K t+$ $\alpha 4 \log F H R t+\alpha 5 \log E X R t+$ et $\ldots 4$

where AGO is agricultural output, CPS is credit rationed for cash crops, FCP is credit rationed for food crops, LSK is credit rationed for livestock farming, FHR is credit rationed for fish farming and EXR is exchange rate variation, $t$ is time, log is logarithm, $\alpha_{\theta}$ is the intercept, $\alpha_{1}, \ldots, \alpha_{5}$ are the coefficients and $e_{t}$ is the error term.

Agricultural output (AGO) is the share of agricultural gross domestic product at current market prices to total GDP. It is expressed in logarithm form. Credit rationing is proxied by the value of the guaranteed agricultural loan. Credit rationed for cash crops (CPS) is measured by summation of the total value of guaranteed loans for oil palm, rubber, cocoa, cotton and groundnuts farming. Credit rationed for food crops farming (FCP) is defined as a total of the value of the agricultural guaranteed loan for grains, roots and tubers farming. Credit rationed for livestock farming (LSK) is the addition of the value of agricultural guaranteed loans meant for poultry, cattle, sheep and other domestic animals. Credit rationed for fish farming (FHR) is defined as the value of agricultural guaranteed loans allocated for the fishery. An increase in the volume of credit rationed for these agricultural purposes is expected to have a positive effect on agricultural output. Also, Exchange rate variation (EXR) is the nominal exchange rate of Naira to the United State of American dollar. Exchange rate is expected to exhibit negative relationship with agricultural output. All the variables are expressed in logarithm form since they are in nominal Naira value. These variables were collated from 1981 to 2016 from Central Bank of Nigeria Statistical Bulletin, 2016.

Equation 4 is analyzed using a cointegration approach since most of the time series data always prove to be non-stationary and also to accommodate endogeneity and simultaneity issues of the production function
ANALYTICAL TECHNIQUES

To ensure the robustness and reliability of the result, the study employed the following techniques: unit root test, co-integration tests, Vector Error Correction Model, Granger Causality Test using E-view statistical package 9.0 version.

\section{UNIT ROOT TEST:}

The time-series properties of data were examined to avoid spurious results emanating from the nonstationary data and to analyze the dynamic structure of the relationship. The estimation began with a unit root test to confirm the stationarity state of the variables that enter the model using Augmented Dickey-Fuller (ADF). The ADF test relies on rejecting a null hypothesis of the unit root (the series are non-stationary) in favour of the alternative hypothesis of stationarity. For instance, if the computed absolute value of the tau statistic $/ T /$ exceeds the ADF critical tau value, then reject the null hypothesis that $\alpha=0$, in which the time series is stationary. But if the computed tau statistic $/ \mathrm{T} /$ value is less than the critical tau value, then do not reject the null hypothesis and therefore conclude that the time series is stationary. Therefore, it is of great importance to test the stationary state of each time series variable.

To overcome such a situation, this study employed Augmented Dickey-Fuller (ADF) and Phillip-Perron (PP) unit root test to ensure that the series used were stationary. Thus, the ADF model of unit test is as follows:

$$
\begin{aligned}
\Delta Y_{t}=\alpha_{0}+Y_{t-1} & +\sum_{i=1}^{n} \alpha_{1} \Delta Y_{t-i}+\delta_{t} \\
& +\epsilon_{t} \ldots \ldots \ldots \ldots \ldots \ldots \ldots \ldots \ldots \ldots \ldots \ldots .5
\end{aligned}
$$

Where $Y$ is a time series, $t$ is a linear time trend, $\Delta$ is the first difference operator, $\varepsilon t$ is a pure white noise error term, $\alpha 0$ is a constant and $n$ is the optimum number of lags in the dependent variable. If the time series variables are non-stationary at level and integration then it becomes an important indication of co-integration within the model. Note, the number of lagged difference terms to include is often determined empirically and the idea is to include enough term so that the error term is serially uncorrelated.

\section{CO-INTEGRATION TEST}

With non-stationary variables, testing whether a stationary long-run relationship (cointegration) exists among the series is equally important because failure to account for cointegration would cause misspecification if the variables are cointegrated, and this might undermine the validity of the parameter estimates (Engle and Granger, 1987). Therefore, a test for cointegration is a pre-test to avoid spurious regression (Granger 1986). There are several techniques for testing for and estimating cointegrating relationships in the literature. Of these techniques, the Johansen and Juselius (1990) maximum likelihood test procedure is the most efficient because it identifies the number of cointegrating vectors between the non-stationary level variables in the context of a vector autoregressive term (VAR).

The study employed the maximum-likelihood test 
procedure established by Johansen and Juselius (1990). Specifically, if $\mathrm{Yt}$ is a vector of $\mathrm{n}$ stochastic variables, then there exists a p-lag vector autoregression with Gaussian errors of the following form.

Additionally, according to Engle and Granger (1987), when variables are found to be I (1), stationary of residual (obtained from a static regression) implies cointegration, meaning that a long-run equilibrium condition exists between the dependent and the independent variables. The residual series is included in the regression as an error correction mechanism. Long run regression results are obtained by the traditional Ordinary Least Squares (OLS) technique. Therefore to observe the nature of co-integration Johansen model was employed as follows:

$\lambda_{\text {trace }}$

$=\sum_{i=r+1}^{n} \operatorname{In}(1$

$\left.-\lambda_{i}\right)$

To determine the number of co-integration vectors, Johansen and Juselius (1990) suggested a statistical test: the first one is the trace test ( $\lambda$ trace).

It tests the null hypothesis that the number of a distinct cointegrating vector is less than or equal to q against a

general unrestricted alternatives $q=r$, this test is shown below.

$\Lambda_{\max }=\quad-\mathrm{T} \quad \ln \quad\left(1-\lambda_{\mathrm{r}+1}\right)$ ….........

Where: $T$ is the number of usable observations, and $\lambda 1$ 's are the estimated eigenvalue from the matrix.

\section{VECTOR ERROR CORRECTION MECHANISM (VECM)}

According to Engle and Granger (1987), co-integrated variables must have an ECM representation. The main reason for the popularity of co-integration analysis is that it provides a formal background for testing and estimating short and long-run relationships among economic variables. However, the ECM strategy provides an answer to the problem of spurious correlations. If two or more variables are co-integrated, the corresponding error correction representation must be included in the system to avoid miss-specification and omission of the important constraints, but on the other hand, if the variables are not integrated of the same order or are not co-integrated, the ECM cannot be applied either (Granger, 1988). Meanwhile, the speed of adjustment of the model from the short run to the longrun equilibrium is higher with the degree of a parameter of ECT. The ECM ( $p)$ form is written as:

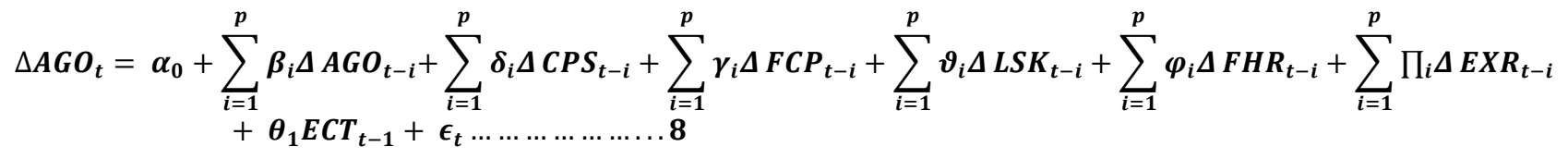

Where AGO represents agricultural output at basic prices, CPS is credit rationed for cash crops farming, FCP is credit rationed for food crops farming, LSK is credit rationed for livestock farming, FHR is credit rationed for fish farming and exchange rate variation respectively. The symbol $\Delta$ indicates the first differences. is the intercept, $\beta, \delta, \gamma, \vartheta, \varphi, \Pi, \theta$, are coefficients, and $p$ is the lag lengths. The maximum lag length, $p$, will be empirically determined including too many lagged terms will consume degrees of freedom and the possibility of multicollinearity. Including too few lags will lead to specification errors. The number of lag term to be introduced in the study will be estimated using the Akaike Information Criterion (AIC).

\section{POST ESTIMATION TESTS}

The study conducted diagnostics tests such as the Breusch-Godfrey test to check the null hypothesis of no autocorrelation, as against the use of the Durbin Watson test, which loses its power in the presence of a lagged dependent variable. In testing for the functional form of the equation, the study employs the Ramsey (1969) RESET test (regression equation specification error tests), which tests whether additional terms of the regressors variables are significant in the auxiliary regression. The significance of these additional variables indicates that the model is misspecified (Gujarati, 2003). The diagnostics tests include Autoregressive Conditional Heteroskedasticity (ARCH) test for heteroskedasticity.
CUSUM test is applied to test for the structural stability of the model. The CUSUM test is based on the Cumulative Sum of the equation errors regression. It is presented graphically the Cumulative Sum of errors together with critical lines of 5 percent. The equation parameters are not considered stable if the whole sum of recursive errors sets outside the two critical lines. Brown et al (1975) proposed two tests Cumulative Sum and Cumulative Sum of Squares, to check the structural stability. CUSUM test captures the systematic changes in regression coefficients, while CUSUMQ detects the departure of parameters from the consistency. Hence, parameter consistency is checked by using the two tests.

\section{RESULTS \\ UNIT ROOT TEST}

The empirical analysis began with the unit root test using Augmented Dickey-Fuller (ADF) and PhillipsPerron (PP) test. These tests were conducted to determine the integration order of the variables to avoid spurious regression. The null hypothesis $(r=0)$ is rejected if the t-statistic is much more in negative than the 5 percent critical value and accepted if otherwise. Also, the null hypothesis can equally be rejected if the pvalue is less than 0.05 and accepted or otherwise. The results of Augmented Dickey-Fuller (ADF) and PhillipsPerron (PP) unit root tests are presented in Tables 1 and 4. 
EGWU, P. N; NNABU, BERNARD E.; MBAM, B. N.; AND NWIBO, S. U.

Table 1: Results of the Augmented Dickey-Fuller Unit Root Test

\begin{tabular}{|c|c|c|c|c|c|c|c|}
\hline \multirow{3}{*}{$\begin{array}{l}\text { Variables } \\
\log (A G O)\end{array}$} & \multicolumn{2}{|c|}{ Level Form } & \multirow[b]{2}{*}{$p$-value } & \multicolumn{3}{|c|}{ First Difference } & \multirow{2}{*}{$\begin{array}{l}\text { Order of } \\
\text { Integration }\end{array}$} \\
\hline & t-Statistics & $\begin{array}{l}5 \% \text { critical } \\
\text { value }\end{array}$ & & t-statistics 5 & $\begin{array}{c}\% \text {-critical } \\
\text { value }\end{array}$ & & \\
\hline & -0.027719 & -3.544284 & 0.9942 & $-4.099934^{*}$ & -3.548490 & 0.0144 & $\mathrm{I}(1)$ \\
\hline $\log (\mathrm{CPS})$ & -3.482144 & -3.544284 & 0.0570 & $-5.926415^{\star}$ & -3.552973 & 0.0001 & $\mathrm{I}(1)$ \\
\hline $\log (\mathrm{FCP})$ & -1.956287 & -3.544284 & 0.6040 & $-5.942977^{*}$ & -3.548490 & 0.0001 & $\mathrm{I}(1)$ \\
\hline $\log ($ LSK $)$ & -2.105190 & -3.544284 & 0.5251 & $-4.941571^{*}$ & -3.548490 & 0.0018 & $\mathrm{I}(1)$ \\
\hline $\log (F H R)$ & -3.098303 & -3.544284 & 0.1224 & $-8.121760^{*}$ & -3.548490 & 0.0000 & $\mathrm{I}(1)$ \\
\hline $\log (E X R)$ & -1.240188 & -3.544284 & 0.8861 & $-5.361648^{*}$ & -3.548490 & 0.0006 & $\mathrm{I}(1)$ \\
\hline
\end{tabular}

Note: * denotes significance at 5 percent level

Source: Author's estimation, 2018

The Augmented Dickey-Fuller test in the level form showed that all the variables have unit or non-stationary since their respective t-statistics are much less than the critical values. This assertion is as well echoed by their probability values ( $p$-values) ware are greater than 0.05 . At first difference, it indicated that the variables tend to stationary as their t-statistics are much more in negative than the critical values. This is supported by their probability values ( $p$-values) which are less than 0.05 . The ADF results indicated that the variables are integrated to order one, which is [I (1)] In a similar vein, Phillips-Perron (PP) was also applied to authenticate the outcome of the ADF test. The results of the PP are presented in Table 2 as follows:

Table 2: Results of the Phillips-Perron Unit Root Test

\begin{tabular}{|c|c|c|c|c|c|c|c|}
\hline \multirow[b]{2}{*}{ Variables } & \multicolumn{2}{|c|}{ Level Form } & \multicolumn{4}{|c|}{ First Difference } & \multirow{2}{*}{$\begin{array}{l}\text { Order of } \\
\text { Integration }\end{array}$} \\
\hline & t-Statistics & $\begin{array}{l}5 \% \text { critical } \\
\text { value }\end{array}$ & p-value & $\mathrm{t}$-statistics 5 & $\begin{array}{l}5 \% \text {-critical } p- \\
\text { value }\end{array}$ & & \\
\hline $\log (A G O)$ & -0.354968 & -3.544284 & 0.9855 & $-3.886788^{*}$ & -3.548490 & 0.0237 & $\mathrm{I}(1)$ \\
\hline $\log (\mathrm{CPS})$ & -3.534225 & -3.544284 & 0.0511 & $-7.788108^{*}$ & -3.552973 & 0.0000 & $\mathrm{I}(1)$ \\
\hline $\log (\mathrm{FCP})$ & -2.051669 & -3.544284 & 0.5537 & $-5.974514^{*}$ & -3.548490 & 0.0001 & $\mathrm{I}(1)$ \\
\hline $\log (\mathrm{LSK})$ & -2.118278 & -3.544284 & 0.5182 & $-4.875189^{*}$ & -3.548490 & 0.0021 & $\mathrm{I}(1)$ \\
\hline $\log (\mathrm{FHR})$ & -3.123737 & -3.544284 & 0.1167 & $-8.130460^{*}$ & -3.548490 & 0.0000 & $\mathrm{I}(1)$ \\
\hline $\log (E X R)$ & -1.277076 & -3.544284 & 0.8772 & $-5.628745^{\star}$ & -3.548490 & 0.0003 & $\mathrm{I}(1)$ \\
\hline
\end{tabular}

Note: * denotes significance at 5 percent level Source: Author's estimation, 2018

The PP test like ADF indicated that all the variables have a unit root at the level form but became stationary after the first difference suggesting that the time series data are integrated of order one, I(1).

\section{CO-INTEGRATION TEST}

The study proceeded to apply the Johansen cointegration test to determine the number of cointegrating equations after having established that all the data series were integrated of order one, I(1). The null hypothesis $(r=0)$ is rejected if the trace and MaxEigen statistics are greater than 0.05 critical value and accepted if otherwise or if the probability value ( $p$-value) is less than 0.05 and accepted if otherwise. The results of these tests are presented in Table 3 as follows: 
Table 3: Results of the Johansen Cointegration Tests

\begin{tabular}{|c|c|c|c|c|c|c|}
\hline \multirow[b]{2}{*}{$\begin{array}{l}\text { Hypothesized } \\
\text { no of } C E(s)\end{array}$} & \multicolumn{3}{|c|}{ Trace Test } & \multicolumn{3}{|c|}{ Maximum Eigen-value Test } \\
\hline & $\begin{array}{l}\text { Trace } \\
\text { Statistic }\end{array}$ & $\begin{array}{l}0.05 \text { Critical } \\
\text { Value }\end{array}$ & Prob $^{\star *}$ & $\begin{array}{l}\text { Max-Eigen } 0 \\
\text { Statistic }\end{array}$ & $\begin{array}{l}.05 \text { Critical } \\
\text { Value }\end{array}$ & Prob** \\
\hline None $^{*}$ & 379.9521 & 95.75366 & 0.0001 & 181.2107 & 40.07757 & 0.0001 \\
\hline At most $1^{*}$ & 198.7413 & 69.81889 & 0.0000 & 84.60972 & 33.87687 & 0.0000 \\
\hline At most $2^{*}$ & 114.1316 & 47.85613 & 0.0000 & 63.98691 & 27.58434 & 0.0000 \\
\hline At most $3^{*}$ & 50.14468 & 29.79707 & 0.0001 & 23.43926 & 21.13162 & 0.0233 \\
\hline At most $4^{*}$ & 26.70543 & 15.49471 & 0.0007 & 22.43670 & 14.26460 & 0.0021 \\
\hline At most $5^{*}$ & 4.268733 & 3.841466 & 0.0388 & 4.268733 & 3.841466 & 0.0388 \\
\hline
\end{tabular}

Note: Trace test and maximum eigen-value indicate 6 cointegrating equations at the 0.05 level, Note: * denotes rejection of the hypothesis at the 0.05 level

Source: Author's estimation, 2018

From table 3 , both the trace and maximum eigenvalue tests proved evidence of cointegration within the model. This is because the critical values of both the trace and max-Eigen statistics are much more than the critical values. Also the probability values of both tests which are less than 0.05 equally attest to the fact that the time series data are cointegrated. In conclusion, the tests proved that six (6) cointegrating equations exist within the model.
The long-run influence of each variable such as credit for cash crops production log(CPS), food crops production $\log (\mathrm{FCP})$, livestock production $\log (\mathrm{LSK})$ and fishery $\log (\mathrm{FHR})$ as well as exchange rate variation $\log (E X R)$ is analyzed using normalized cointegrating equations. The results of normalized cointegrating equation between the dependent variable and independent variables are presented as follows:

Table 4: Results of Long Run Effect of Credit Rationing on Agricultural Output

\begin{tabular}{|c|c|c|c|c|c|}
\hline \multicolumn{6}{|c|}{ Normalized cointegrating coefficients } \\
\hline $\log (A G O)=$ & $-\log (\mathrm{CPS})+$ & $\log (\mathrm{FCP})$ & $\log ($ LSK $)+$ & $\log (\mathrm{FHR})$ & $\log (E X R)$ \\
\hline coefficient & $-0.264771^{*}$ & $0.435215^{*}$ & $-0.758688^{*}$ & $0.418889^{\star}$ & $-1.161791^{*}$ \\
\hline Std. error & $(0.01243)$ & $(0.02688)$ & $(0.01006)$ & $(0.01839)$ & $(0.01853)$ \\
\hline t-statistic & -21.3182 & 16.1910 & -75.4163 & 22.7781 & -62.6978 \\
\hline
\end{tabular}

From table 4, it is observed that credit meant for cash crops production $\log (\mathrm{CPS})$, livestock production $\log (\mathrm{LSK})$ and exchange rate variation $\log (\mathrm{EXR})$ exhibited negative long-run relationship with agricultural output in Nigeria. However, credit meant for food crops production and fishery shows a positive long-run impact on agricultural output. The t-statistics of coefficients of the parameter estimates of CPS, FCP, LSK, FHR, and EXR exhibited a high level of significance, suggesting that these variables have a significant long-run impact on agricultural output. The credit for cash crops $\log (\mathrm{CPS})$ and livestock $\log (\mathrm{LSK})$ production had negative impact on agricultural output while credit for food crops $\log (\mathrm{FCP})$ and fishery $\log (\mathrm{FHR})$ production significantly and positively influenced agriculture. The negative signed exchange rate $\log (E X R)$ is an indication that its depreciation, growth-enhanced agricultural output in the long run.

\section{ERROR CORRECTION MODEL RESULTS}

Since the cointegration showed evidence of at least one cointegrating equation, it necessary to apply a vector error correction model (VECM) to ascertain the short-run dynamics within the model. The null hypothesis is rejected if the probability value ( $p$-value) of the parameter estimate is less than or equal to $0.05(P \leq 0)$ and accepted if otherwise. The result of the vector error correction model (VECM) is presented in Table 5 as follows: 
EGWU, P. N; NNABU, BERNARD E.; MBAM, B. N.; AND NWIBO, S. U.

Table 5: Results of Short-run Effect of Credit Rationing on Agricultural Output

\begin{tabular}{|c|c|c|c|}
\hline & Coefficient & t-Statistic & Prob. \\
\hline ECT(-1) & $-0.113245^{*}$ & -4.094600 & 0.0006 \\
\hline$\Delta(\log (\mathrm{AGO}(-1)))$ & $0.323514^{*}$ & 2.319607 & 0.0317 \\
\hline$\Delta(\log (\mathrm{AGO}(-2)))$ & $-0.302784^{*}$ & -2.629664 & 0.0165 \\
\hline$\Delta(\log (\mathrm{CPS}(-1)))$ & 0.030848 & 1.114365 & 0.2790 \\
\hline$\Delta(\log (\mathrm{CPS}(-2)))$ & 0.028493 & 0.887587 & 0.3859 \\
\hline$\Delta(\log (\mathrm{FCP}(-1)))$ & -0.063886 & -0.846623 & 0.4077 \\
\hline$\Delta(\log (\mathrm{FCP}(-2)))$ & 0.099805 & 1.615536 & 0.1227 \\
\hline$\Delta(\log (\operatorname{LSK}(-1)))$ & 0.089479 & 1.883404 & 0.0750 \\
\hline$\Delta(\log (\operatorname{LSK}(-2)))$ & 0.023996 & 0.439291 & 0.6654 \\
\hline$\Delta(\log (\mathrm{FHR}(-1)))$ & -0.014495 & -0.617996 & 0.5439 \\
\hline$\Delta(\log (F H R(-2)))$ & $-0.105009^{*}$ & -5.132209 & 0.0001 \\
\hline$\Delta(\log (\operatorname{EXR}(-1)))$ & $-0.201476^{*}$ & -2.177461 & 0.0423 \\
\hline$\Delta(\log (\operatorname{EXR}(-2)))$ & -0.005884 & -0.078363 & 0.9384 \\
\hline C & $0.239053^{*}$ & 5.178749 & 0.0001 \\
\hline R-squared & 0.839199 & \multirow{3}{*}{\multicolumn{2}{|c|}{$\begin{array}{ll}\text { Durbin-Watson Stat } & 2.199895 \\
\text { Prob(F-Stattistic) } & 0.000049\end{array}$}} \\
\hline Adjusted R-squared & 0.729177 & & \\
\hline F-statistic & 7.627578 & & \\
\hline
\end{tabular}

Note: * denotes significant at 5 percent level

Source: Author's estimation, 2018

Table 5 shows the short run impact of credit rationing on agricultural output in Nigeria. The result indicated that previous years of agricultural output (AGO-1 and AGO2) exhibited a significant short-run impact on current agricultural output. The result indicated that in first lag of agricultural output significantly resulted in $32.35 \%$ rise in current agricultural output while the second year lag led to $30.23 \%$ decline in current agricultural output. On the other hand, credit rationed for cash crop production (CPS-1 and CPS-2), food crops (FCP-1 and FCP-2), and livestock (LSK-1 and LSK-2) were statistically insignificant in the short run. These shows that credit rationed for cash crops, food crops and livestock do not growth-enhanced agricultural output in the short run.

The first lag of credit rationed for fishery production (FHR-1) is statistically insignificant while the second lag is significant. The significance of the second lag parameter suggested that credit rationed for fishery in the second year resulted in decline in agricultural output in the short run to the tune of $10.5 \%$. However, the first lagged exchange rate (EXR-1) was statistically significant and as well exhibited expected negative relationship with agricultural output in the short run. Therefore, depreciation of the exchange rate in the first lagged period led to a $20.15 \%$ rise in agricultural output while the second lagged period is insignificant though negative.

The R-squared of 0.839199 indicated that 83.91 percent variation in agricultural output is explained by the explanatory variables. This showed that it is a good fit. The F-statistic of 7.62758 revealed that explanatory variables jointly influenced agricultural output (AGO). The Durbin-Watson statistic of 2.199895 showed the absence of autocorrelation among the residuals.

The presence of short-run adjustment to long-run equilibrium is determined with the t-statistic of ECT(-1). The ECT has the expected negative sign and its coefficient of -0.113245 showed that short-run disequilibrium is corrected by $11.32 \%$ per annum until equilibrium is achieved in the long run.

\section{POST ESTIMATION TESTS RESULTS}

The following diagnostic tests: normality test, autocorrelation, heteroskedasticity, specification, and CUSUM tests were conducted to determine to ascertain the reliability of regression estimates. The null hypotheses of these tests are accepted if their respective probability values are less than 0.05 which will suggest normal distribution, no autocorrelation, homoskedastic and no specification error. The results of these tests are presented as follows:

Table 6: Diagnostic Tests Results

\begin{tabular}{llll}
\hline Post Test & F-Statistic & df & p-value \\
\hline Jarque-Bera Normality Test & 1.113057 & 33 & 0.573195 \\
Breusch-Godfrey Serial Correlation LM Test & 0.205972 & 2,17 & 0.8159 \\
Heteroskedasticity Test (ARCH) & 0.399048 & 1,30 & 0.5324 \\
Specification Test (Ramsey RESET Test) & 0.628608 & 1,29 & 0.4343 \\
\hline
\end{tabular}

Note: * denotes significant at 0.05 levels

Source: Author's estimation, 2018 
Table 6 shows the post estimation test results on the relationship between credits rationing by deposit money banks on agricultural output in Nigeria. Meanwhile, since the $p$-values of Jarque-Bera, Breusch-Godfrey and autoregressive conditional heteroskedasticity and specification test are greater than 0.05, it indicated that all the variables are normally distributed, no presence of autocorrelation, the errors are homoskedastic and the model is well specified. Also, the CUSUM tests were

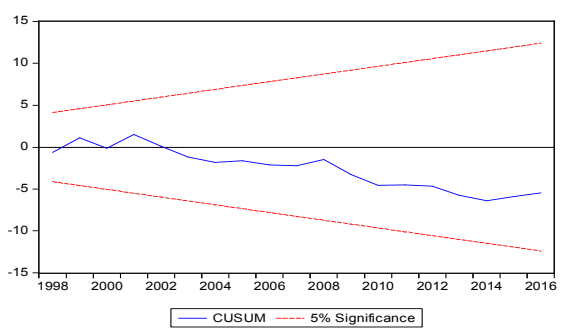

Figure A performed to determine the structural stability within the model. The CUSUM test shows the graphical cumulative sum of errors together with critical lines of 5 percent. The CUSUM test measures the variation in the parameters and considered unstable if the recursive errors crossed the critical lines while the lines of CUSUMQ investigate the consistency of the parameters. The results of the CUMSUM tests are presented in Figure 1 as follows:

Figure 1: CUSUM Test Results

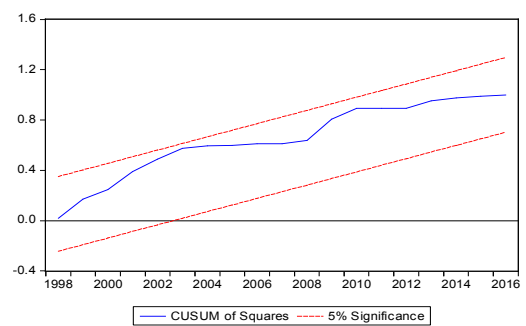

Figure B

Source: Author's estimation, 2018

From Figure 1, since the CUSUM and CUSUMQ lie within critical boundaries at a 5 percent level, it indicated that there is long-run stability of parameter estimates. This revealed consistency of parameter estimates. The results show that there is long-run stability between credit rationing by deposit money banks and agricultural output.

\section{CONCLUSION}

The study carried out a controlled experiment using econometric models and tests as well, to trace the effect of credit rationing by deposit money banks on agricultural output growth in Nigeria from 1990 to 2015. The findings showed that credit rationing by deposit money banks, for fish farming has a significant short-run impact while those rationed for cash crops, food crops, livestock farming had insignificant short-run effects on agricultural output growth. These imply that credit rationed for cash crops, food crops, and livestock farming has not been adequate to significantly influence agricultural output in the short run. Also, the underdeveloped nature of Nigeria's agricultural sector may have hindered banks from lending adequate credit for the growth of the agricultural subsectors.

The result indicated that credit rationing has a significant long-run effect on agricultural output in Nigeria. It was observed that credit rationing by deposit money banks to agriculture in Nigeria has long term effects on the agriculture sector. $\mathrm{CBN}$ monetary policy could be said to have inadequately controlled loan rationing by deposit money banks to agriculture. However, based on the results, there is hope that improvement in the financial issues as it concerns loan approvals by deposit money banks to agriculture, intermediation, and creation of special schemes through which investment funds could be made available to agriculture and other economic units at lower cost will improve agricultural output in the long run.

\section{RECOMMENDATIONS}

The following recommendations were made based on the findings of the study to aid policymakers in the determination of their policies. The recommendations are as follows:

1. Monetary authorities should set up a special financial institution that will be saddled with the responsibility of providing loans to cash crops farming. This will improve credit availability for cash crops farming which will invariably boost its output in the long run.

2. Credit rationing for food crop production should be raised above the current ceiling. This will stimulate food crop farming which is pivotal for the country to achieve food sufficiency.

3. Government credit rationing intervention in livestock farming should be on short-term bases since such intervention aids agricultural output only in the short-run.

4. The emphasis monetary authorities should be on long-term promotion of fishery faring in Nigeria. Therefore, credit rationed for fishery should designed in a manner that it will achieve long fishery faring which has been adjudged to promote agricultural output.

5. Monetary authorities should emphasize on exchange rate liberalization policy that will shift consumption from imported agricultural produce to local agricultural produce. This will serve as an incentive for local farmers to increase their output to meet the local demand.

\section{REFERENCES}

Akoten, J. E., Sawada, Y., and Otsuka, K., 2006. The determinants of credit access and its impacts on micro and small enterprises: The Case of Garment Producers in Kenya. Economic Development and Cultural Change, 54(4), 924944.

Arene, C. J., 1992. Loan repayment and technical assistance among small holder maize farmers in Nigeria. African Review of Money, Finance and Banking, 4: 13-36. 
Armstrong, A., Davis, P. E., Liadze, L., and Rienzo, C., 2013. Evaluating changes in banking lending to UK SMEs over 2001-12. Ongoing Tight Credit? Department for Business and Innovation and Skills. London.

Asante-Addo, C., Mockshell, J., Siddig, K., and Zeller, M., 2016. Agricultural credit provision: What really determines farmers' participation and credit rationing? Invited paper presented at the 5th International Conference of the African Association of Agricultural Economists, September 23-26, 2016, Addis Ababa, Ethiopia.

Atzeni, G., and Piga, C., 2007: R\&D Investment, Credit Rationing and Sample Selection. International Industrial Organization Society Conference. Chicago.

Ayeomoni, I. O., and Aladejana, S. A., 2016. Agricultural credit and economic growth nexus. evidence from Nigeria. International Journal of Academic Research in Accounting, Finance and Management Sciences, 6(2), 146-158. DOI: 10.6007/IJARAFMS/v6-i2/2099.

Barbosa, G. and Moraes, C., 2004. Determinants of the firm's capital structure: The case of the very small enterprises. Retrieved from.

Beck, T., 2007. Financing constraints of SMEs in developing countries: Evidence, determinants and solutions. Journal of International Money Finance, 31(2), 401-441.

Bigsten, A., Collier, P., Dercon, S., Fafchamps, M., Gauthier, B., Gunning, J. W., and Söderbom, M., 2003. Credit constraints in manufacturing enterprises in Africa. Journal of African Economies, 12(1), 104-25.

Blumberg, B. F., and Latterie, W. A., 2008. Business starters and credit rationing. Small Business Economics, 30, 187-200.

Brown, R. L., Durbin, J., and Evans, J., 1975. Techniques for testing the constancy of regression relationship over time. Journal of Royal Statistical Society, Series (B), 149 - 163.

Carbo-Valverde, S., Degryse, H. and RodriguezFernandes, F., 2011. Lending relationships and credit rating: The Impact of Securitization. $24^{\text {th }}$ Australian Finance and Banking Conference Paper Chakravarty.

Cecilia, A. N., Omonona, B. T. and Victor, O. O., 2012. Microfinance and poverty reduction in Nigeria: $A$ Critical Assessment. Australian Journal of Business and Management Research, 2(4), 3340.
Chan, S., and Kanatas, G., 1985. Asymmetric valuation and the role of collateral in loan agreements. Journal of Money, Credit and Banking, 17(1), 85-95.

Chen, K.., and Chivakul, M., 2008. What drives household borrowing and credit constraints? Evidence from Bosnia and Herzegovina. IMF Working Paper WP/08/202. Washington, DC: International Monetary Fund.

Coco, G., 2000. On the use of collateral. Journal of Economic Survey, 14(2), 191-214.

Doan, T., Gibson, J., and Holmes, M., 2010. What determines credit participation and credit constraints of the poor in peri-urban Areas, Vietnam? MPRA (Munich Personal RePEc Archive) Paper No. 27500. Hamilton, New Zealand: Economics Department, University of Waikato.

Duong, P., and Izumida, Y., 2002. Rural development finance in vietnam, a micro econometric analysis of household Surveys. World Development Economic Review, 59, 850-72.

Emil, S., 2007. Prerequisites of credit rationing in a bank-company relationship in empirical approach. Research Undertaken in Collegium of Management and Finance, Warsaw School of Economics.

Eneji, M. A., Umejiakwu, R., Sylvannus, O., and Gwacham-Anisiobi, I., 2013. The demand for credit, credit rationing and the role of microfinance: Evidence from poor rural communities in cross river state. Science Journal of Economic, 30(20), 319-335. doi: $10.7237 / \mathrm{sje} / 139$.

Engle, R. F., and Granger, C. W. J., 1987. Cointegration and error - correction: representation, estimation, and testing, Econometrica, 55, 251 276.

Granger, C. W. J., 1986. Investigating causal relations by econometric models and cross-spectral methods. Econometrica, 37, 424 - 438.

Granger, C. W. J., 1988, Investigating causal relations by econometric models and cross-spectral methods. Econometrica 14, 227 - 238.

Gujarati, D., 2003. Basic econometrics. Fourth edition, New York: McGraw Hill Publishing Company.

Idris, O. B., 2010. Review of small farmer access to agricultural credit in Nigeria. International Food Policy Research Institute (IFPRI), 3, 2-11. 
Jaffee, D. M., Russell, T., 1976. Imperfect information, uncertainty, and credit rationing. Quarterly Journal of Economics, 90, 651-66.

Jimenez, G., and Saurina, J., 2003. Collateral, type of lender and relationship banking as determinants of credit risk. Madrid: Bank of Spain.

Johansen, S. and Juselius, K., 1990. Maximum likelihood estimation and inference on cointegration with application to the demand for money. Oxford Bulletin on Economics and Statistics, 52(2), 169 - 210.

Kofarmata, Y. I., Applanaidu, S. D., and Hassan, S., 2014. Determinants of participation in credit market among the farmers in Northern Nigeria. Proceedings Book of ICETSR, 2014, Malaysia Handbook on the Emerging Trends in Scientific Research, pp 429 - 439.

Nzotta, S. M., 2004. Money, banking and finance. Owerri: Hudson-Jude Nigeria publishers of Nigeria's Banking Industry.

Olomola, A., 1999a. Agricultural credit market imperfections and implications for lending to smallholders in Nigeria. In A. S. Olomola and S. O. Akande (eds). Agricultural Finance Issues in Nigeria. Ibadan: Nigerian Institute of Social and Economic Research.

Olomola, A. S., and Gyimah-Brempong, K., 2014. Loan demand and rationing among small-scale farmers in Nigeria. International Food Policy Research Institute (IFPRI) Discussion Paper 01403 pp $1-25$.

Omorokunwa, O. G., and Obadiaru, E. D., 2016. Credit constraint and agricultural output in Nigeria. Sokoto Journal of the Social Sciences, 6(1), 172 $-185$.

Ramsey, J., 1969. Tests for specification errors in classical linear least squares regression analysis. Journal of the Royal Statistical Society, $31(2), 350-371$.

Salami, A., Kamara, A, B., and Brixiova, Z., 2010. Smallholder agriculture in east Africa: Trends and productivity. Journal of Agriculture, Biotechnology and Ecology, 4(3), 2953.

Sanusi, W. A., and Adedeji, I. A., 2010. A probit analysis of accessibility of small-scale farmers to formal source of credit in Ogbomosho zone, Oyo State, Nigeria. Agricultural Tropica et Subtropica, 43(1), 49-53.

Steijvers, T., 2008. Existence of credit rationing for SME's in the Belgian corporate bank loan market. Available at http://ssrn.com/abstract $=495162$ http://dx.doi.org/10.2139/ssrn. 495162.

Stiglitz, J. E. and Weiss, A., 1981. Credit ration in markets with imperfect information. American Economic Review, 71(3), 393-410.

Subbotin, A., 2005. Determinant of credit rationing for corporate farms in Russia. European Annunciation of Agriculture Economics, 9, 426436.

Sugato, C., and Chakravarty, A., 2002. Analysis of agricultural credit rationing by deposit banks in Nigerian. Central bank of Nigeria (CBN) Economic Reviews, 3, 20-29.

Von Pischke, J. D., 2008. The political economy of farm credit in Kenya. Ann Arbor, Michigan: University Microfilms.

Tian, J., 2012. Formal credit rationing and productivity in Chinese agriculture. Fifth International Joint Conference on Computational Sciences and Optimization, Harbin, 2012, pp. 189-191, doi: 10.1109/CSO.2012.48. 